2. As an initial sign of this lesion, congestion or hyperemia of capillaries in submucous layer of the esophagus is histologically observed. Following increased permeability of capillaries serous transudate appears and then edema, hemorrhagia per diapedesin or rhexin and cell infiltration take place.

In the second stage fibrin appears in the edematous, region, and sometimes organization process, varix like formation or change of glandular ducts are demonstrated.

3. Not only these histopathological changes but also the characteristic tendency of patients to worry about cancer, tuberculosis or ascaris in the laryngo-esophageal region are of impotance in the concept of this lesion, as those people with extreme traits of neurosis are liable to manifest severe subjective symptoms.

\title{
Refarences
}

(1) S. Niho, K. Yoshio, S. Inaba: The Journal of the Japan Broncho-Esophagological Society ; Vol. 2, No. 1, P. 6.1951.

(2) K. Yoshio : Otolaryngology Tokyo: Vol.22, No. 5, P. 215. 1950.

(3) S. Inaba : Otolaryngology Tokyo: Vol. 22, No. 7, P. 309. 1950.

(4) N. Takahata : Yokohama Medical Journal ; Vol. 3, No. 1-2, P. 1. 1952.

(5) S. Niho, T. Iwatake, N. Takahata : The Journal of the Japan

Broncho-Esophagological Society ; Vol. 5, No. 1, P. 18. 1954.

\section{Histological Studies on the Nervous System of the Lung}

* by Nobuo Inaba

I wish to report on a few findings I made while taking histological studies on the structure of the nervous system of the lung since 1954 .

The lungs of men and dogs were used as materials of my studies and Suzuki's modification of Bielschowsky's silver impregnation and Sugamo's staining method of myelin sheath were chiefly employed as staining method of the nerve as shown in Slide No. 1.

As is well known, nerve control of the lung is performed by sympathetic, vagal and phrenic nerve, the nerve fibers of which from anterior and posterior pulmonary plexus at the root of the lung. The nerve fibers from the plexus are distributed to the lung accompanying the bronchi and pulmonary vessels as shown in Slide No. 2. Numerous nerve fibers are also distributed to the pulmonary pleura forming a nerve network as shown in Slide No. 3. The bundles of nerve fibers that run along the bronchi are rel-

* Surgical Division of the Tuberculosis Research Institute, Kyoto University

$$
68-68
$$


ayed on their way by many ganygiion cells as shown in Slide No. 4, but no ganglion cells are observed on the pulmonary artery wall. These ganglion cells are multipolar ganglion cells that belong to the autonomic nervous system as shown in Slide No. 5, and postganglionic nerve fibers from them distribute their branches in the lung. The nerve fibers that are distributed in the lung can be classified into, as shown in Slide No. 6, from functional as well as from histological point of view. One is the afferent nerve fibers that are of viscero-sensory nervous system, and the other is the efferent nerve fibers that are of autonomic nervous system.

Sensory nerve terminations of viscero-sensory nervous system that is, the afferent nerve fibers, are composed of large-sized thick myelinated nerve fibers and can be recognized at a glance to be sensory as their extremities end freely.

These sensory nerve terminations are distributed to the bronchi, the parenchyma of the lung, the pulmonary vessels and the pulmonary pleura. The sensory nerve terminations in the parenchyma of the lung shown in Slide No. 7 probably have to do with pulmonary-vagal reflex, that is, Hering-Brauer's reflex. Slide No. 8 sho'vs the sensory nerve terminations distributed to the pulmonary arteries, while Slide No. 9 presents those of puImonary veins. These sensory nerve terminations are probably related to the pressoreceptive regulation.

It was the existence of peculiar sensory nerve terminations that attracted my attention, which I observed in tunica muscularis mucosa of the bronchi as shown in Slide No. 10, as they seemed to be related to pressoreceptive regulation. They seem to be the grertest source of causing the vago-vagal reflexes as the drop of blood pressure and circulatory insufficiency often observed while treating the hilum during pulmonary resection, judging from their peculiar histological condition.

The autonomic nervous system that means efferent nevre fibers is of motoric, secretory and vasomotoric nerve fibers that are composed of the sympathetic nerve fibers and the para-sympathetic nerve fibers. The nerve terminations of these are distributed to the bronchi, the parenchyma of the lung, pulmonary vessels and the pleura as terminal reticulum composed of very find mesh-work of the neurofibrils.

Distributing condition of the vasomotoric nerve fibers to the pulmonary vessels is especially characteristic. Slide No. 11 shows the vasomotoric nerve fibers distributed to the pulmonary artery, and, as you see, the vasomotoric nerve fibers distributed to the pulmonary arteries and veins are generally more sparsely distributed than those of the bronchial arteries and veins. The vasomotoric nerve fibers of the pulmonary veins are more sparsely distributed than those of the pulmonary arteries as shown in Slide No. 12. From such conditions, it is presumed that the control of the vasomotoric nerve fibers to the pulmonary vessels is rather feeble.

Autonomic nerve fibers to the bronchi are distributed to the tunica propria, the tunica submucosa and the bronchial smooth muscles as shown in Slide No. 13 and end in terminal reticulum as shown in Slide No.14. These autonomic nerve fibers seem to control bronchial contraction and dilation.

$$
69-69
$$


These are the summarized results of my studies on the structure of the nervous system of the lung from the histological and functional point of view.

\section{Die Narkosetechnik \\ fur bronchologische Eingriffe im Kindesalter.}

* Dr. H. Friedel

Wir sahen soeben den schönen, eindrucksvollen Film von Herrn Professor Dayto, wie an der Universitätsklinik in. Tokyo bronchologische Eingriffe im Kindesalter durchgeführt werden. Dieser Film gestattet mir, mein Referat unter Verzicht auf einleitende Ausführungen in lebendiger Weise gewissermassen als Ergänzung zu der japanischen. Arbeitsweise abzuhandeln. Man zieht auch in Japan die allgemeine Betäubung beim Kinde in Form einer intravenös induzierten Barbituratnarkose vor. Dies feststellen zu können, war mir eine besondere Genugtuung, ist doch auch unsere Arbeitsweise auf die Vermeidung jeglichen psychischen Traumas abgestimmt. Nach der Nerkoseeinleitung wurde ein MuskelrelaxaneSuccinylcholin-verabreicht, die Spontaneatmung jedoch nicht vollkommen ausgeschaltet. Auch wir benutzen beim Kind nach den eingehenden Untersuchungen vor Stead das Succinylcholin als "Muskelrelaxane der Wahl", vertreten jedoch in der Anwendung von muskellähmenden Substanzen zu bronchologischen Eingriffen eine andere Konzeption; Wir fordern eine vollwertige künstliche Beatmung, unabhängig davon, ob eine komplette Atemlähmung erreicht oder nur eine Hypoventilation angestrebt wird. Wir haben es ja nicht in der Hand, ob nach einer Succinylcholin-Dosis das beabsichtigte, noch erlaubte Ausmass. der Ventilationseinschränkung eintritt oder ob wir nicht doch mit einer-wenn auch kurz dauernden-Atemlähmung rechnen müssen. Im übrigen bringt auch die Hypoventilation, insbesondere bei den sekret-reichen kindlichen Atemwegen, Gefahren mit sich, die wir nicht unterschützen dürfen. Es sind dies die unbemerkt fortschreitende Kohlensäureakkumulation und Hypoxämie. Aưf der anderen Seite bietet uns gerade die komplette Atemlähmung Vorteile, die beim Kind nicht noch genug veranschlagt werden können : Z.B. ist jetzt erst der Introitus laryngis reflexlos und macht es möglich, schonend und atraumatisch zu intubieren.

Die Ruhe im Bronchialbaum und die zeitliche Unabhängigkeit ermöglichen dem Bronchologen eine höchstmögliche Konzentration, die bei den kleien kindlichen Verhültnissen für diagnostische und therapeutische Manipulationen besonders erstrebenswert ist.

Diese Vorteile konnten seither nur da genutzt werden, wo ein Narkoseapparat vorhanden und ein Teamwork mit einem Anaesthesiologen möglich war. Um die Narkosemethode einem

* Sehr verehrter Herr Präsident! Meine Damen und Herren!

$$
70-70
$$

